\title{
Achievement Culture in National Examination at Junior High School
}

\author{
Subur $^{1 *}$, Istania Widayati Hidayati ${ }^{1}$ \\ ${ }^{I}$ Department of Islamic Studies, Universitas Muhammadiyah Magelang, Magelang, Indonesia \\ "Corresponding author.Email: subur@ummgl.ac.id
}

\begin{abstract}
High Grades of National Examination Score is school's success indicator in gaining academic achievements. The schools will compete in improving the quality of their educational processes by encouraging students to get high grades at the Computer-Based National Examination (CBNE). This study aims to identify school culture and its implementation at junior high schools that achieve the best achievements in the academic field in Magelang Regency. The method used in this study is the evaluative approach with qualitative descriptive analysis. Data collection techniques use observation, in- depth interviews and documentation. The results show that the existence of positive school cultures is honesty, discipline, competitive, cooperation, hard work, and religious. The process of implementing school culture is carried out by starting school activities earlier than the other school in general. It implies that the culture can be used as the reference to improve school's performance.
\end{abstract}

Keywords: culture, achievement, National Examination

\section{INTRODUCTION}

Education in a school is essentially to transform cultural values with goals developing, and maintaining the culture of a society. Developing school values, behavior, plans and strategies is a way to maintain the school culture that will be followed by all school members [1]. Minister of Education and Culture Regulation Number 32 Year 2018 about Technical Minimum Service Standards Education mandates that Minimum Service Standards [2] aims to equalize the quality of teaching and learning both in urban and rural areas. But the facts on the ground show that there are differences in quality about student learning outcomes. It can be seen from the achievements obtained by students, including the scores obtained at the Computer-Based National Examination.

A study states that the things that affect student learning achievement include values that apply in schools and the culture of school organizations [3]. Meanwhile, to improve good school is to improve physical and non- physical culture [4]. Values that underlie behavior, daily habits, traditions and symbols that are practiced by the school community and the community around the school are called school culture. The whole series of activities and school cultural routines will lead students to the achievements. But researchers may still not prioritize that the role of parents in shaping the culture of high school achievement is very influential. The form of school culture of achievement includes four points, namely: a balance between academic and non-academic coaching, cultivation of character through learning, alma mater love culture and the importance of spiritual values [5].
Why culture is important is because if a positive culture is embedded in the school environment then the transfer / transfer of teachers will not significantly influence student achievement. This research focuses more on the school culture that involves parents of students in supporting the process of student success in school, which is a form of supervision and a form of parental attention to their children at home, which is a form of supervision and a form of parental attention to their children at home [6]. However, this research is more focused to find out what school culture can improve student achievement, especially in obtaining the highest rank of junior high school national exams in Magelang district in particular and Central Java in general. The majority of research that has been carried out by school culture researchers are matters relating to students' selfesteem, infrastructure, values, and the additional learning process at school. But there has been no research that specifically discusses the important role of parents in the success of the National Examination. This study has a concept of how the role of parents in providing services and efforts to prepare students who are ready to face the National Examination that begins with activities to increase learning hours, tryouts and motivation for students. SMPN 1 Muntilan is a junior high school that has achieved academic achievements, which has the highest average score in Central Java each year. This is interesting to study why schools can make it happen while zoning has also been applied in schools in Magelang Regency.

This study aims to identify school culture, find out how to implement school culture and analyze the influence of school culture on high achieving junior high schools in Magelang Regency. Muntilan 1 Middle School is one school that has a myriad of achievements and cultural characteristics that are different from other schools. Lots of achievements have been obtained by these schools both at local and national levels. In the academic field of SMPN 1 Muntilan, it is the highest school in Central Java in 20172018. 


\section{METHODS}

This research approach is a qualitative descriptive that aims to express symptoms in full and the relationship between each other in the aspects to be studied. The location of this research is in SMPN 1 Muntilan Magelang Regency. The focus of this research can be broken down into three issues including: the culture of the school that achieves the national exams, its implementation and development. This research uses primary data and secondary data. Primary data were obtained from research subjects, namely school principals, teachers, students, parents and education personnel. Secondary data were obtained from school data, the SMPN 1 website, as well as the code of conduct and recap of achievements and madding magazine at the school. While the data collection techniques used are observation, interview, documentation and comparison [7]. The data collection process was carried out quite rigorously without disturbing the teaching and learning process at the school. The data collection process was carried out quite rigorously without disturbing the teaching and learning process at the school. For observation activities carried out by visiting the place related to the problem to be solved starting from the facilities and infrastructure, writing, symbols, buildings, and interactions with school residents and the perception of the community around SMPN 1 Muntilan. While the data obtained were analyzed by qualitative descriptive analysis with data display, data analysis and conclusions.

\section{RESULTS AND DISCUSSION}

\subsection{School culture of achievement}

School culture is a whole system of ideas of actions and results of human work in the context of life that belongs to the human self by learning. Achievement school culture provides an understanding that with achievement it shows that the process undertaken in teaching and learning activities in schools is in the context of establishing a healthy culture in the community. School culture will also affect the classroom atmosphere, be it class freedom or even class restraints on the minds and achievements of students. The culture of the school built will certainly greatly determine the quality and student achievement.

Culture at school when learning in the classroom will greatly affect students when outside the classroom. Students while in the school environment will follow the culture that has been created at school. The learning process will run according to what has become the rules and plans that have been made by the teacher and of course the culture is in accordance with the values in the community.

School culture is the most important thing in a school. The most important motivation for students is achievement motivation, where the achievement is intended to train a child to succeed or fail. Bearing in mind that achievement varies greatly. A child may not be intellectually clever but behaviorally can show achievements or vice versa children who are academically unachievable but non-academically have talent as well as achievement. But in general children who excel both in academic and non-academic fields will have a high level of enthusiasm and motivation in living life in the future, which is embraced by his family and community.

\subsection{Profile SMPN 1 Muntilan}

SMPN 1 Muntilan Public Middle School is the oldest firstlevel secondary education institution under the auspices of the Magelang District Youth and Sports Education Office. Initially (before 1946) was the Regional Government Junior High School (SMP)Pemda. Starting in 1946, it changed its name to SMP Negeri 1 Muntilan. Subsequently in 1971 received the title as a Pioneer Junior High School, 1978 as a Model Junior High School, in 2002 as a National Standard School (SSN), and in 2008 the government was designated as one of the International Standard School Pilot Projects (RSBI). Geographically, the location of SMPN 1 Muntilan is very strategic because it is located in the city of Muntilan and is on the city's main street, Jl. Youth No.161 Muntilan. With such a strategic location, SMPN 1 Muntilan is very accessible for students and communities throughout Muntilan City and surrounding areas. The vision of SMPN 1 Muntilan is "the realization of an intelligent, moral, cultured, and superior person in achievement". In addition, it also has a vision of service that is "The Realization of PRIMA 1 Muntilan Middle School Service Quality.

Furthermore, this school code is intended as a signpost for students to behave, say, act and carry out daily activities in school in order to create a climate and culture of the school that can support effective learning activities. This school code of conduct is based on the values adopted by the school and surrounding communities, which include: the values of piety, social courtesy, discipline and order, cleanliness, health, neatness, security and values that support effective learning activities. The culture of SMPN 1 Muntilan which was built among others: honesty culture, discipline culture, literacy culture, cooperation culture, religious culture.

\subsubsection{Honesty Culture}

The culture of honesty at SMPN 1 Muntilan was built to give students an understanding that one's success is supported by honesty. Conversely, someone's loss is due to dishonesty in completing work in the future. Honesty culture is introduced to students by spensamart and honesty canteen. By seeing the development of Spensa Mart from its inception having capital which is increasingly growing means that the culture of honesty is truly upheld. It is indeed intended to instill honest behavior in students. Given the behavior of lying, as well as the culture of paying not in accordance with the original is often done by teenagers. Next is the culture of returning money found by students to the BK teacher or homeroom teacher. This shows that students in SMPN 1 Muntilan really understand that something that is not their property must be returned. The 
culture of honesty will certainly bring happiness in the future, because there are many thieves or corruptors because there is no honest nature and behavior in a person. In SMPN 1 Muntilan there was a perception that there were no cheating exams so without strict supervision there were no students cheating.

Honesty is a school culture that is instilled in SMPN 1 Muntilan. According to interviews conducted and direct observation that SMPN 1 Muntilan has developed an honest culture practiced by all school members. It can be seen from the honesty canteen and Spensa Mart as well as the honesty of a student who reported to the BK teacher that he found one sheet of IDR 100,000.00. Honesty canteens in some schools may not last long due to the lack of honest culture in some schools in Magelang Regency but that did not happen at SMPN 1 Muntilan. Even the canteen can survive and benefit at the same time. Spensa Mart (SMP Negeri One Mart) which was established 3 years ago with a capital of IDR 4,000,000.00 has now reached a turnover of IDR 16,000,000.00. This indicates that the value of honesty instilled in schools has succeeded in forming a positive culture in SMPN 1 Muntilan.

\subsubsection{Discipline Culture}

The culture of discipline that is built up among others students will come to school at $07.00 \mathrm{WIB}$ to study the scriptures of each of them intended to foster a love of religion, learn about their respective religions. The duration of time needed is 15 minutes. While the apple teacher at 07.00 WIB. Whereas for class IX come at 06.00 WIB to work on the exam questions that will be discussed at the extra hours in the afternoon at $14.00 \mathrm{GMT}+7$.

\subsubsection{Collaboration Culture}

Collaboration with parents' association to support school activities. It starts with a coordination meeting with parents and how to prepare class IX students starting from the preparations already at home school and attention at breakfast. Cooperation with parents is considered most important in the form of supervision and at the time of evaluation will invite parents to be able to actively participate in learning activities. Then bring in motivators from SMPN 1 Muntilan alumni who have successfully become teachers or lecturers or entrepreneurs to motivate students to be more enthusiastic in reaching their goals.

\section{CONCLUSION}

The conclusion of this study is that almost all schools studied have the same routine in order to face the national exam. Starting from additional learning time, try out, quarantine, motivation and religious activities. But in SMPN 1 Muntilan there is a culture that has not been done by other schools. Namely the culture of collaboration with parents in the success and delivery of students achieving achievements in the academic field. Collaboration with parents is in the form of supervision, physical and psychological preparation of students in preparing for examinations. With a school culture that can be realized properly and adequate supervision from the school, the role of the teacher is not the only determinant of student success and achievement. If there is a teacher mutation will not affect student achievement because the school culture is well embedded. The culture of collaboration between schools and parents of students is the result of this study. For this reason, apart from a culture of honesty, literacy and discipline, other schools with the same level in Magelang Regency should always develop good communication and cooperation with parents.

\section{ACKNOWLEDGMENT}

This research was funded by LP3M-Universitas Muhammadiyah Magelang in 2019.

\section{REFERENCES}

[1] Y. Agus, - Jurnal komunitas, „I J. Komunitas, vol. 3, no. 2, pp. 169-179, 2011.

[2] Depdikbud, Peraturan Menteri Pendidikan dan Kebudayaan Tahun 2018. Jakarta, 2018.

[3] Fitriani, —Budaya Sekolah Untuk Meningkatkan Prestasi Akademik,\| J. Visi Ilmu Pendidik., vol. 10, no. 1, pp. 1006-1017, 2013.

[4] F. N. kartikasari Ratnasari Diah Utami, Mulat Kurniasih, - Implementasi Penerapan sekolah Ramah Anak pada Penyellenggaraan Pendidikan Sekolah Dasar,\| 5th Urecol Proceeding, vol. 18, no. February, pp. 170-176, 2017.

[5] R. Abdi, - Pengembangan Budaya sekolah di SMAN 3 Tanjung Kabupaten Tabalong Kalimantan Selatan,\| J. Penelit. dan Eval. Pendidik., vol. 2, no. x, pp. 191-200, 2007.

[6] P. Raharjo, -Manajemen Budaya SMPN 1 Kajen Pono,\| Educ. Manag., vol. 2, no. 1, pp. 131-135, 2013.

[7] L. J. Moeloeng, Metodologi Penelitian Kualitatif, 2nd ed. Bandung, 2005. 